\title{
Effect of Biochar Application on Soil Carbon Fluxes from Sequential Dry and Wet Cultivation Systems
}

\author{
Mahmudul Islam Piash"1, Md. Faruque Hossain ${ }^{2 *}$, Ihuoma N. Anyanwu ${ }^{3}$, Shamim Al Mamun ${ }^{4}$, \\ Zakia Parveen ${ }^{1}$ \\ ${ }^{1}$ Department of Soil, Water \& Environment, University of Dhaka, Dhaka, Bangladesh \\ ${ }^{2}$ American International University-Bangladesh, Dhaka, Bangladesh \\ ${ }^{3}$ Department of Biology/Microbiology/Biotechnology, Federal University Ndufu-Alike Ikwo, Ikwo, Nigeria \\ ${ }^{4}$ Department of Environmental Science and Resource Management, Mawlana Bhashani Science and Technology University, \\ Tangail, Bangladesh \\ Email: ^hossainfaruque@hotmail.com, ^mfhossain@aiub.edu
}

How to cite this paper: Piash, M.I., Hossain, Md.F., Anyanwu, I.N., Al Mamun, S. and Parveen, Z. (2018) Effect of Biochar Application on Soil Carbon Fluxes from Sequential Dry and Wet Cultivation Systems. American Journal of Climate Change, 7, 40-53.

https://doi.org/10.4236/ajcc.2018.71005

Received: November 15, 2017

Accepted: March 2, 2018

Published: March 5, 2018

Copyright (c) 2018 by authors and Scientific Research Publishing Inc. This work is licensed under the Creative Commons Attribution International License (CC BY 4.0).

http://creativecommons.org/licenses/by/4.0/

\begin{abstract}
Application of biochar has been highly credited for its potential to sequester carbon and GHG mitigation from tropical agro-ecosystems. However, experiments show inconsistent results depending on soil and biochar type, cultivation system, climatic condition and the type of evolved GHGs. This study emphasized on the effect of biochar on carbon emission trends from a sequential dry and wet cultivation system of Bangladesh. An incubation study was conducted with two contrasting soils and eight different treatments viz. control, only fertilizer, three different biochars $\left(10 \mathrm{t} \cdot \mathrm{ha}^{-1}\right)$ with and without recommended fertilizer dose. Results revealed the fact that, emission of carbon was substantially higher from Sara soil than Kalma soil. Biochar treatments did not have any easing effect on $\mathrm{CO}_{2}$ emission at field condition; rather, increased in most of the cases. However, emission was significantly $(\mathrm{P}<$ $0.05)$ suppressed at submerged condition by biochar application. Non-fertilized water hyacinth biochar was most effective in this regard. In general, fertilizer application caused higher emission of $\mathrm{CO}_{2}$. Biochar application was ineffective to control $\mathrm{CH}_{4}$ and $\mathrm{CO}$ release to atmosphere and submergence further intensified their emission significantly. The overall results indicate that applied biochars have negligible effect on carbon emission except for reducing $\mathrm{CO}_{2}$ from submerged soils.
\end{abstract}

\section{Keywords}

Greenhouse Gases, Carbon Emission, $\mathrm{CO}_{2}, \mathrm{CH}_{4}, \mathrm{CO}$, Emission from Submergence 


\section{Introduction}

The global climate is changing rapidly due to simultaneous emission of anthropogenic greenhouse gases (GHG) into the atmosphere since the pre-industrial era [1]. During the past few decades, total concentrations of $\mathrm{CO}_{2}, \mathrm{CH}_{4}$ and $\mathrm{N}_{2} \mathrm{O}$ in the atmosphere increased at rates of $0.5 \%, 0.8 \%$ and $0.3 \%$, respectively [2]. Therefore, surface temperature has increased about $0.78^{\circ} \mathrm{C} \pm 0.06^{\circ} \mathrm{C}$ since the last 19th century [3]. Agricultural activities are one of the major reasons of elevated GHG concentrations in the atmosphere. Total GHG emission from agriculture is estimated to be $1.4-1.6 \mathrm{Gt}$ (Gigaton) $\mathrm{CO}_{2}-\mathrm{C}$ equivalent $\left(\mathrm{CO}_{2}-\mathrm{C}_{\mathrm{e}}\right)$ year $^{-1}$ which is approximately $12 \%-14 \%$ of total human-induced warming effect [4]. Therefore, it is high time to take serious steps to reduce the agricultural emission of GHGs to mitigate climate change.

Application of biochar has been vastly credited for its potential role to sequester carbon while applied to soil [5] [6] [7] [8]. It is the solid by-product of pyrolysis process which converts biomass physio-chemically in an oxygen limited condition, which is, resistant to microbial decomposition and can also reduce the agricultural emission of carbonaceous gases [9]. Biochar can seize about $50 \%$ of the carbon in biomass. When biochar is applied to soil, the carbon is sequestered for centuries. Thus, biochar reduces the overall atmospheric $\mathrm{CO}_{2}$ by removing $\mathrm{C}$ from the active cycle and sequestering it that also enhances plant growth, which takes more $\mathrm{CO}_{2}$ out of the atmosphere. It can also reduce the emission of $\mathrm{N}_{2} \mathrm{O}$ and other gases significantly. Moreover, many studies have proved biochars capability to enhance soil fertility, moisture retention and intern increased plant growth [10] [11]. Biochar can efficiently work as a soil amendment particularly in highly weathered tropical soils.

However, the GHG mitigation potential of biochar is highly variable depending on soil and feedstock type, biochar production temperature, climatic condition, farmland management (dry or wet), crop species etc. [12]. Some laboratory and field trials have showed increased GHG fluxes after biochar incorporation while others showed no significant effect [13]. For instance, application of wheat straw biochar on maize field caused a $12 \%$ increase of $\mathrm{CO}_{2}$ flux while reduced $41.8 \%$ of $\mathrm{N}_{2} \mathrm{O}$ and $9.8 \%$ of methane emission [14]. A meta-data analysis of Song et al. (2016) reveals the fact that biochar application significantly decreases $\mathrm{CO}_{2}$ emissions by $5 \%$ in paddy fields but increases $\mathrm{CO}_{2}$ emissions by $12 \%$ in upland fields [15]. Low biochar application rates $\left(\leq 10 \mathrm{t} \cdot \mathrm{ha}^{-1}\right)$ decreased $\mathrm{CO}_{2}$ emissions. Biochar derived from wood (including soft and hard woods) significantly increased $\mathrm{CO}_{2}$ emissions by an average of $21 \%$, whereas biochar derived from husk significantly decreased $\mathrm{CO}_{2}$ emissions. Slow-pyrolysis Biochar $\left(\leq 500^{\circ} \mathrm{C}\right)$ significantly increases $\mathrm{CO}_{2}$ emissions [15]. Moreover, application of urea fertilizer results higher emission of nitrous oxide and $\mathrm{CO}_{2}$ from soils [16].

In contrast, very little is known regarding the effects of biochar on total $\mathrm{CH}_{4}$ emission though its global warming potential is 28 times higher than $\mathrm{CO}_{2}$. Moreover, rice fields are a potential source of $\mathrm{CH}_{4}$, emitting approximately 
$31,112 \mathrm{Tg}$ (Teragram) globally [17]. Approximately 57\% of rice is grown in irrigated or continuous flooded fields under extremely anaerobic conditions globally, which ultimately encourages methane emission. Single studies of $\mathrm{CH}_{4}$ emission have frequently reporting ambiguous results. A study of Jeffery et al. (2016) reveals that biochar can substantially mitigate $\mathrm{CH}_{4}$ emissions from soils, particularly from flooded (i.e. rice) fields and/or acidic soils [18].

Carbon monoxide is not considered as a direct GHG but it has indirect effects on increasing other greenhouse gases. It reacts with hydroxyl radicals reducing their concentration in the atmosphere which in turn helps to reduce the lifetime of strong GHGs like $\mathrm{CH}_{4}$. Scientists have already proposed that $\mathrm{CO}$ should have a GWP because of their stimulating effects on other greenhouse gases [19]. Potter et al. (1996) demonstrate a model where they estimated gross production of

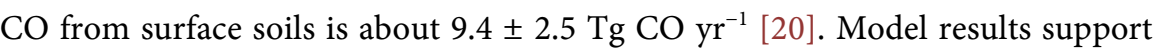
the assumption that temperate dry zones are the major global sinks for soil CO, whilst tropical wet zones are the major sources for soil CO production.

Biochar could be a promising option for carbon sequestration and soil amendment for tropical countries like Bangladesh as it has very low organic carbon content in it's soils (approximately 1\%) and her economy largely depends on agriculture. According to a report on GHG Footprint of Nations, per capita carbon footprint of Bangladesh was only 1.1 tons year $^{-1}$ in 2001 but 55\% of it comes from the food sector [21]. Besides, FAO Rice Market Monitor (2017) predicted Bangladesh will remain the fourth largest rice producing country in the world and rice fields are one of the major sources of methane emission [22]. Model-based estimation says Bangladesh will emit nearly $653 \mathrm{Gg}$ (Gigagram) of $\mathrm{CH}_{4}$ in 2030 and approximately $906 \mathrm{Gg}$ in 2050 from paddy fields if the water management practice remains the same [23]. However, very limited laboratory or field-based experiments have been conducted to quantify the actual carbon emission trends from rice-dominated and sequential dry-wet cultivation practices of Bangladeshi agro-ecosystem. Considering the cropping system and different soil types of Bangladesh, the main objective of this study is to investigate the carbonaceous GHG's emission behaviors in both winter crops and submerged rice production, effect of fertilizer application and biochar type etc. This analysis is expected to improve our understanding of GHG emission patterns from Bangladeshi agro-ecosystems and the probable impact of biochar on carbon fluxes to mitigate national contribution towards climate change.

\section{Materials and Methods}

The experiment was conducted with two benchmark soils of Bangladesh with contrasting characteristics. The first one was the Sara series collected from Rarikhal village, Shreenagar Upozilla, under Munshigonj district, Bangladesh. The geo-location of the sampling site was between $23^{\circ} 32^{\prime} \mathrm{N}$ to $23^{\circ} 39^{\prime} \mathrm{N}$ and $90^{\circ} 13^{\prime} \mathrm{E}$ to $90^{\circ} 23^{\prime} \mathrm{E}$. The Sara is a calcareous fluvisol which belongs to Ganges river floodplain covering 249,798 hectares of land. The soil is poorly to moderately well 
drained, silty loam, slightly alkaline, $\mathrm{pH}$ ranges from 7.1 to 8.2 and used as an agricultural land. The Kalma soil was collected from Shreenpur Upozilla, Gazipur, Bangladesh. The geo-location of the sampling site located between $24^{\circ} 01^{\prime} \mathrm{N}$ to $24^{\circ} 21^{\prime} \mathrm{N}$ Latitude and $90^{\circ} 21^{\prime} \mathrm{E}$ to $90^{\circ} 33^{\prime} \mathrm{E}$. Kalma soil series belongs to Modhupur tract physiology, medium highland and well drained and $\mathrm{pH}$ ranges from 4.8 to 6.1 , acidic in nature, belongs to silty clay textural class. Vegetables are usually grown; tree plantation is common. Both soil samples were collected from surface to a depth of $0-15 \mathrm{~cm}$ by composite soil sampling method as described in Soil Survey Staff of USDA [24].

Feedstocks for biochar production were selected on their availability throughout Bangladesh and considering the best use of municipal organic wastes. Farmyard manure (FM) and water hyacinth (WH) were collected from the farmyards of Sreenagar Upozilla of Munshigonj District (adjacent to Padma River). The domestic organic waste (DW) was collected from a typical apartment building's daily waste generated at Uttara, Dhaka. The collected feedstocks were appropriately treated before biochar production (slow pyrolysis) at about $380^{\circ} \mathrm{C} \pm 20^{\circ} \mathrm{C}$. Produced biochars were analyzed for their physicochemical properties and nutrient content [25] before applying into the soils.

\subsection{Experimental Setup}

The incubation experiment consisted of eight different treatments for both the soils with 3 replicates each. The treatments include control, only fertilizer, three different biochars $\left(10 \mathrm{t} \cdot \mathrm{ha}^{-1}\right)$ with and without recommended fertilizers (Table 1). Similar fertilizer doses were applied in both the soils as recommended in online fertilizer recommendation system of Soil Resources Development Institute (SRDI) [26].

\subsection{The Design of the Gas Trapping Container}

To trap and measure the evolved gases from incubated soils, specially designed plastic containers of $5 \mathrm{~L}$ volume were used. Those containers were procured from the local market. At first, all the containers were washed properly with

Table 1. Treatment combination for the conducted experiment.

\begin{tabular}{ccc}
\hline $\begin{array}{c}\text { Treatment } \\
\text { No. }\end{array}$ & Arrangement of experiments & Symbol/Designation \\
\hline 1 & Control soil & C \\
2 & Soil + Fertilizer & F \\
3 & Soil + Farmyard manure Biochar & FM \\
4 & Soil + Water Hyacinth Biochar & WH \\
5 & Soil + Domestic Organic waste Biochar & DW \\
6 & Soil + Farmyard manure Biochar + Fertilizer & FM + F \\
7 & Soil + Water Hyacinth Biochar + Fertilizer & WH + F \\
8 & Soil + Domestic Organic waste Biochar + Fertilizer & DW + F \\
\hline
\end{tabular}


distilled water, dried in sunlight and labeled. Two holes were made in each container to serve two different purposes; one is to insert adequate water when necessary and another one for the measurement of the evolved gases. The first hole was made on the sides of each container and was sealed with a rubber stopper that facilitates one-way entry of a syringe needle for watering the incubated soil. The second hole was made on the top of the lid with the exact size of the suction tube of Gas-analyzer. Plastic syringes were used to insert water where necessary. Each hole was sealed with cotton, sellotape, rubber band and foil paper. The foil paper and sellotape were only removed when it was time for gas measurement and watering the soils.

Each container received $3 \mathrm{~kg}$ of air-dried soils and adequate biochar \& fertilizer treatments. The soils in the containers were kept in $50 \%$ saturated water condition, up to 60 days, representing the Rabi crops cultivated at field condition. Thereafter, those were waterlogged under $2 \mathrm{~cm}$ of standing water for next 60 days representing subsequent rice cultivation of the Kharif season. Each container had $3200 \mathrm{~mL}$ of free space above the soil.

Emission of both direct and indirect Greenhouse gases $\left(\mathrm{CO}_{2}, \mathrm{CH}_{4}\right.$ and $\left.\mathrm{CO}\right)$ was analyzed in every 15 days interval. Two machines were used to measure the gases (Figure 1): For the measurement of $\mathrm{CO}_{2}$ and $\mathrm{CH}_{4}$, a portable 800-5 $\mathrm{CO}_{2} / \mathrm{CH}_{4}$ Gas Meter was used which is manufactured by the Columbus Instruments. This machine gives the results on a percentage basis. Apart from this, Indoor Air Quality Monitor Kit manufactured by Graywolf sensing solutions was used to measure $\mathrm{CO}$ emission. This machine gave the reading in $\mathrm{ug} \cdot \mathrm{m}^{-3}$ unit.

Calculation: $\mathrm{CO}$ emission was first converted to \% gas in the container from ug. $\mathrm{m}^{-3}$ unit.

Occupied gas in the container: $3200 \mathrm{~cm}^{3}$.

Volume occupied by only $\mathrm{CO}_{2} / \mathrm{CH}_{4} / \mathrm{CO}$ in the container): (\% gas $\left.* 3200\right) / 100$.

Equivalent $\mathrm{CO}_{2} / \mathrm{CH}_{4} / \mathrm{CO}$ release from 1 hectare $\left(\right.$ in $\left.\mathrm{cm}^{3}\right)$ : (vol. of gas $*$ $2,000,000) / 3$

Now, according to the gas law: $\mathrm{V}_{1} \mathrm{~T}_{1}=\mathrm{V}_{2} \mathrm{~T}_{2}$.

Here,

$\mathrm{V}_{1}=$ volume of $\mathrm{CO}_{2} / \mathrm{CH}_{4} / \mathrm{CO}$ released from 1 hectare.

$\mathrm{T}_{1}=$ temperature of that day (temperature ranged from $22.5^{\circ} \mathrm{C}$ to $34.6^{\circ} \mathrm{C}$ during the incubation period).
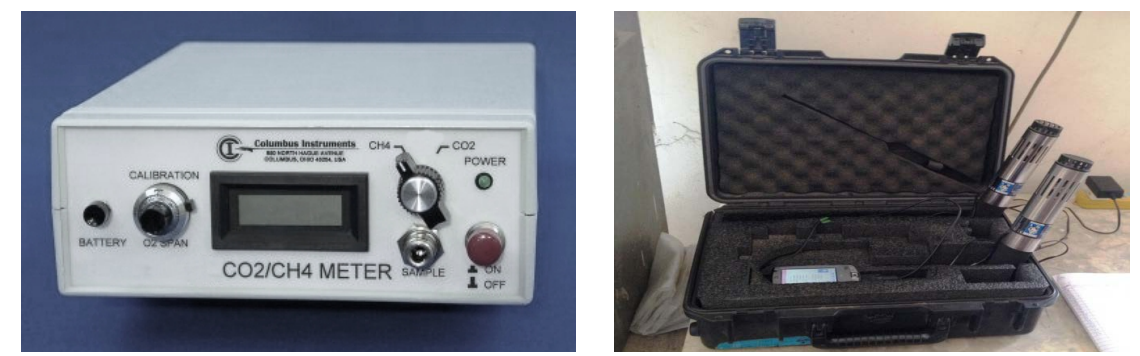

Figure 1. Portable $\mathrm{CO}_{2} / \mathrm{CH}_{4}$ meter and Indoor air qualities monitor kit. 
$\mathrm{V}_{2}=$ volume of gas at STP.

$\mathrm{T}_{2}=298 \mathrm{~K}$.

Therefore, $\mathrm{V}_{1}=\mathrm{V}_{2} \mathrm{~T}_{2} / \mathrm{T}_{1}$.

Again, we know, $\rho=\mathrm{m} / \mathrm{v}$.

where, $\rho=$ density.

$\mathrm{M}=$ mass.

$\mathrm{V}=$ volume of gas.

Now, amount of emitted gas, $\mathrm{m}=\rho \star \mathrm{v}\left(\mathrm{kg} \cdot \mathrm{ha}^{-1}\right)$.

Emission of evolved $\mathrm{CO}_{2}$ and $\mathrm{CH}_{4}$ were represented by $\mathrm{kg} \cdot \mathrm{ha}^{-1}$ and emitted $\mathrm{CO}$ was $\mathrm{g} \cdot \mathrm{ha}^{-1}$ unit. Equivalent $\mathrm{CO}_{2}\left(\mathrm{CO}_{2} \mathrm{e}\right)$ emission was calculated by multiplying the mass of $\mathrm{CH}_{4}$ with 28 (GWP) for 100 years of lifetime.

Statistical analyses were done using Stata version 14.0. Analysis of variance was done to investigate significant variations among the treatments.

\section{Results and Discussions}

\subsection{Effect on $\mathrm{CO}_{2}$ Emission}

From Sara soil, the $\mathrm{CO}_{2}$ emission at first sampling date $\left(15^{\text {th }}\right.$ day) reveals that all the biochar applied treatments expelled more $\mathrm{CO}_{2}$ than the other two treatments (control and only fertilized) (Figure 2). This curve of emission remained static for next three sampling dates i.e. up to $60^{\text {th }}$ day of incubation. Which means that, at field condition, the emission of $\mathrm{CO}_{2}$ was considerably higher in biochar treated soils than the control and the sole-fertilized-one. These high emission rates of $\mathrm{CO}_{2}$ after biochar incorporation might be due to the sudden increase in soil organic matter content. At $30^{\text {th }}$ day of incubation, the emission of $\mathrm{CO}_{2}$ dramatically increased for all the treatments; ranged from nearly doubled to as much as six times (for fertilized farmyard manure biochar treatment) than the first recording date. This may be attributed to increase decomposition of organic matter by a maximum number of microorganisms between $15^{\text {th }}$ to $30^{\text {th }}$ day. On average, the highest emission of $\mathrm{CO}_{2}\left(950 \mathrm{~kg} \cdot \mathrm{ha}^{-1}\right)$ after 15 days of incubation was due to the application of fertilized domestic waste biochar $(\mathrm{DW}+\mathrm{F})$; which is nearly double than the average emission of control soil of Sara. The overall

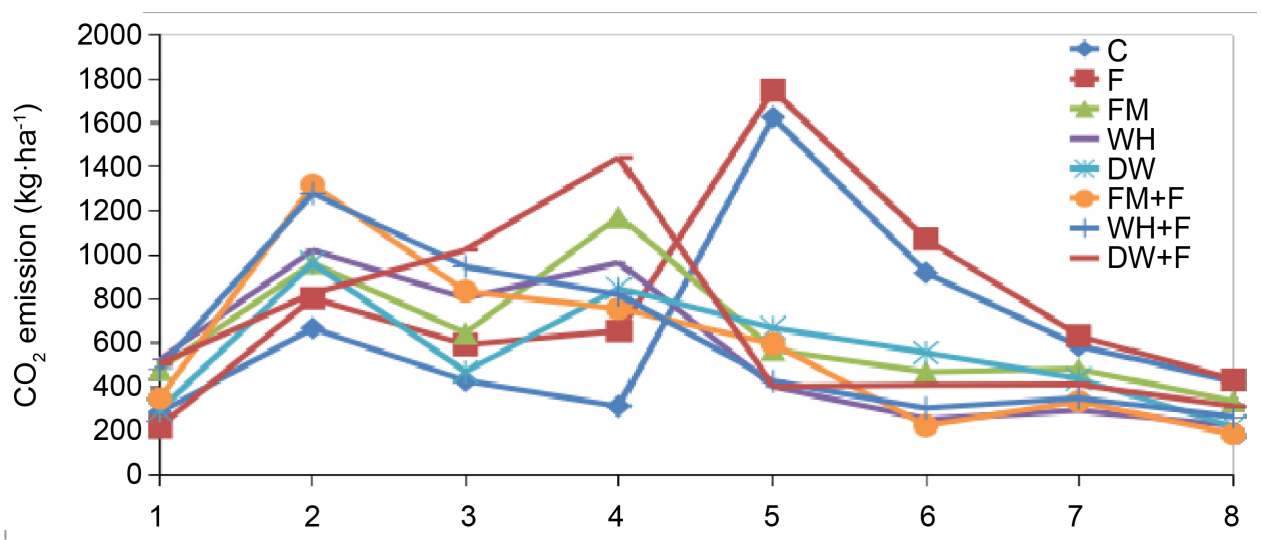

Figure 2. Change in $\mathrm{CO}_{2}$ emission behaviors from Sara soil. 
behavior of $\mathrm{CO}_{2}$ emission in field condition illustrated an alternating increase and decrease pattern from $15^{\text {th }}$ to $60^{\text {th }}$ day which is highly significant $(\mathrm{p}<0.001)$. However, no significant variations were recorded among the biochar treatments or by the application of fertilizer on $\mathrm{CO}_{2}$ emission.

Fifteen days after introduction of the submerged condition, suddenly the lowest $\mathrm{CO}_{2}$ emitting treatments of Sara soil became the highest emitter. The only fertilized treatment became the principal emitter with $1748 \mathrm{~kg} \cdot \mathrm{ha}^{-1}$ followed by the control $\left(1625 \mathrm{~kg} \cdot \mathrm{ha}^{-1}\right)$. Similar trends of increased soil $\mathrm{CO}_{2}$ fluxed immediately after flooding were seen by a group of scientist, exceeded pre-flooding values by two-thirds [13] [27]. This increase is unexpected and pulse like. Water hyacinth biochar, which was among the highest emitting treatments, became the least emitter ( $\mathrm{WH}+\mathrm{F}$ and $\mathrm{WH}$, respectively) at this stage. In next 45 days, overall $\mathrm{CO}_{2}$ emission reduced and the difference in emission from the treatments became gradually smaller. Overall, only fertilized treatments emitted $972 \mathrm{~kg} \cdot \mathrm{ha}^{-1}$ per 15 days which is approximately 3 times higher than water hyacinth biochar treatment $\left(293 \mathrm{~kg} \cdot \mathrm{ha}^{-1}\right)$. The effect of biochar treatments in reducing $\mathrm{CO}_{2}$ emission from submerged condition was significant at 5\% level. All the biochar treatments were significantly effective in reducing $\mathrm{CO}_{2}$ emission; especially non-fertilized water hyacinth biochar (WH). Increasing incubation period also significantly $(\mathrm{p}<0.05)$ reduced emission from Sara soil.

The overall $\mathrm{CO}_{2}$ emission from Kalma soil (Figure 3) was comparatively lower than that of Sara. This may be due to the low inherent organic $\mathrm{C}$ content of the soil along with initial acidic $\mathrm{pH}$. At first sampling date, the highest emitter was the domestic waste biochar treated soil with $506 \mathrm{~kg} \cdot \mathrm{ha}^{-1}$ followed by the $\mathrm{WH}+$ $\mathrm{F}$ treatment $\left(501 \mathrm{~kg} \cdot \mathrm{ha}^{-1}\right)$. The lowest emission was from the FM treatment; only $133 \mathrm{~kg} \cdot \mathrm{ha}^{-1}$. After next 15 days of incubation, five of the eight treatments showed increased emission. For next two recording dates (45th and 60th days) $\mathrm{CO}_{2}$ emission lessened down. At both the stages, farmyard manure biochar applied soils emitted the highest $\mathrm{CO}_{2}$. Throughout the field condition, neither the treatments nor the fertilizer application caused any significant variation.

Resembling Sara, control and only fertilized treatment of Kalma soil saw an increase in $\mathrm{CO}_{2}$ emission after the introduction of the submerged condition. At

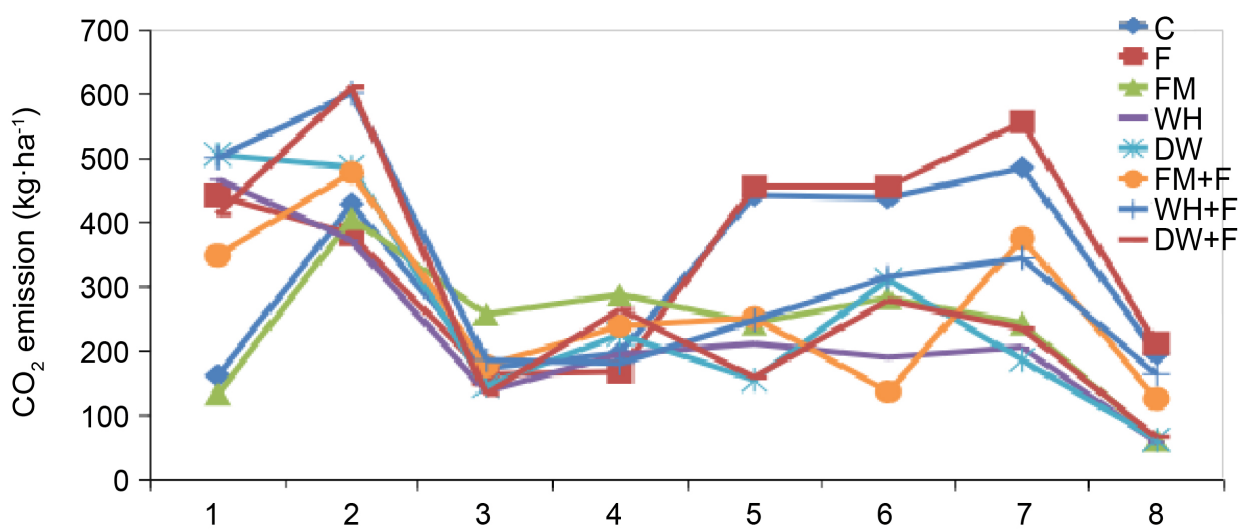

Figure 3. Change in $\mathrm{CO}_{2}$ emission trends from Kalma soil. 
75th days of incubation, the maximum emission is from the only fertilized soil followed by control. During the next three recording date of submerged condition, either the control soil or the only fertilized one was the main emitter. The peak emission $\left(557 \mathrm{~kg} \cdot \mathrm{ha}^{-1}\right)$ of Kalma soil was observed at $105^{\text {th }}$ day of incubation from the fertilized soil. At the end of the incubation period, emission of $\mathrm{CO}_{2}$ became very low like $58 \mathrm{~kg} \cdot \mathrm{ha}^{-1}$ per 15 days for WH. In this submerged condition, biochars effect on suppressing the emission of $\mathrm{CO}_{2}$ was significant $(\mathrm{p}<$ 0.05 ) and water hyacinth biochar (without fertilizer) come out to be the best treatment for this.

Results show that the average of each 15 days $\mathrm{CO}_{2}$ emission from both the soils in field condition and submerged condition is $525 \mathrm{~kg} \cdot \mathrm{ha}^{-1}$ and $388 \mathrm{~kg} \cdot \mathrm{ha}^{-1}$, respectively. At field condition, biochar did not have the appreciable $\mathrm{CO}_{2}$ reducing effect; it even increased for most of the treatment. However, the effect of biochar on suppressing the emission of $\mathrm{CO}_{2}$ was significant in submerged conditions for both the soils. A similar trend was observed in the laboratory after biochar application in waterlogged paddy soil [28] and they attributed such results to the restriction in methanogen activity, limitation on microbial biomass carbon and the rise in $\mathrm{pH}$ value. In general, fertilized biochar treatments expelled an elevated amount of $\mathrm{CO}_{2}$ compared to their non-fertilized counterparts; however, the effect was not significantly proved. This study supports the findings of several scientists in terms of $\mathrm{CO}_{2}$ emission from upland and paddy fields [13] [15]. They also revealed the fact that, lower biochar application rates $\left(\leq 10 \mathrm{t} \cdot \mathrm{ha}^{-1}\right)$ decrease $\mathrm{CO}_{2}$ emissions which comply with this experiment at the submerged condition. Therefore, a range of factors like soil and biochar type, soil moisture level and fertilizer application determined the emission of $\mathrm{CO}_{2}$ from this experiment.

\subsection{Effect on $\mathrm{CH}_{4}$ Emission}

At first recording date of Sara soil, the Control (C) and fertilized domestic waste biochar $(\mathrm{DW}+\mathrm{F})$ treatment both caused the lowest emission of $\mathrm{CH}_{4}(3.22$ $\left.\mathrm{kg} \cdot \mathrm{ha}^{-1}\right)$, whereas, the $\mathrm{FM}+\mathrm{F}$ observed highest emitting treatment $\left(9.65 \mathrm{~kg} \cdot \mathrm{ha}^{-1}\right)$ (Figure 4). At second sampling date, methane emission was undetectable by the

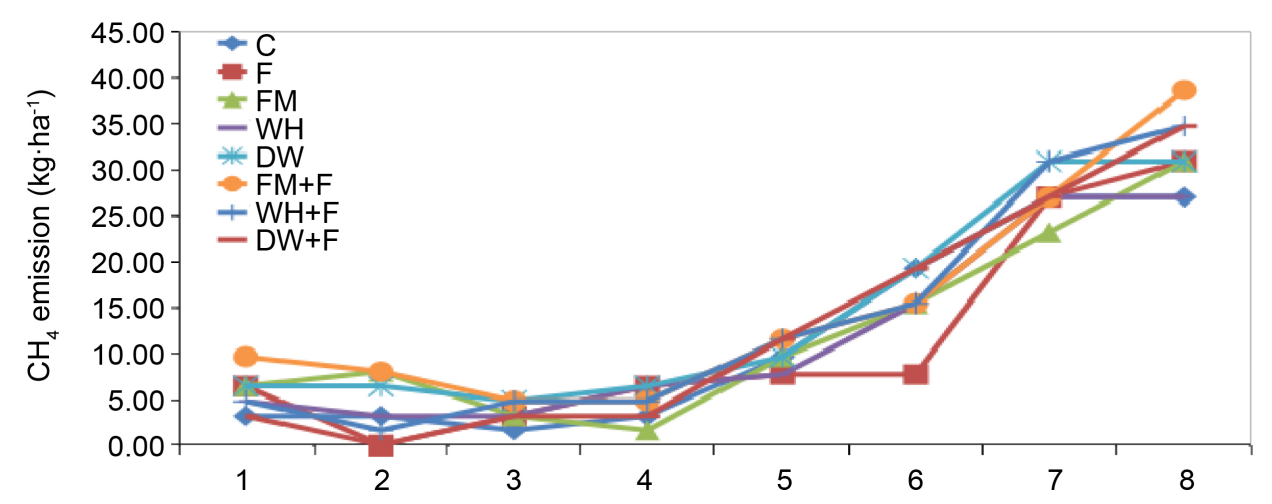

Figure 4. Change in $\mathrm{CH}_{4}$ emission from Sara soil. 
machine from both $\mathrm{F}$ and $\mathrm{DW}+\mathrm{F}$ treatments. Emission declined slightly for treatments in $3^{\text {rd }}$ sampling period and the overall emission increased a little at the $4^{\text {th }}$ date of recording for fertilized biochar treatments. The $\mathrm{CH}_{4}$ emission was comparatively lower than $\mathrm{CO}_{2}$ from incubated soils which might be due to the prevalence of aerobic microbes.

However, after the introduction of the submerged condition, the changed moisture regime caused predicted increase in $\mathrm{CH}_{4}$ emissions from almost all the treatments. Overall emission increased gradually until the end of the experimental period. During the submerged condition, biochar treatments with fertilizer emitted a higher amount of $\mathrm{CH}_{4}$ than that of non-fertilized or control soils.

Biochar treatments increased considerable amount of $\mathrm{CH}_{4}$ emission from both field and submerged condition in Sara soil, though it was not significantly proven. Average emission in submerged condition was significantly $(\mathrm{p}<0.001)$ higher than field condition (nearly 4 times). The effect of fertilizer on $\mathrm{CH}_{4}$ emissions was not significantly proved in Sara soil.

The $\mathrm{CH}_{4}$ emission was a bit higher in field condition from Kalma soil (Figure 5) than that of Sara. Very little variations were noticed among the emission behavior treatments revealing the fact that biochar treatments did not affect the pattern of emissions. In submerged condition, $\mathrm{CH}_{4}$ emissions fall slightly from $75^{\text {th }}$ to $90^{\text {th }}$ day. However, by the end of the experiment, a minor rise in $\mathrm{CH}_{4}$ emission including a sharp increase from 90th to 105th days was seen. Fertilized biochar treatments were seen to be the highest emitter here as well. By the end of the incubation period, fertilized water hyacinth biochar treatment became the highest emitter from submerged Kalma soil with $28.96 \mathrm{~kg} \cdot \mathrm{ha}^{-1}$.

Results reveal that biochar treatments did not have any significant effect on $\mathrm{CH}_{4}$ emission either in field or in submerged condition. Like the Sara soil, emission from Kalma soil was not significantly affected by fertilizer application.

Many studies have found reduced emission of $\mathrm{CH}_{4}$ from biochar incorporated soils [18] [27] [28]. The $\mathrm{CH}_{4}$ emissions reduced are credited mainly to the effects of biochar on soil physicochemical factors and changes in the activity of methanogens that generate $\mathrm{CH}_{4}$ and increases in the abundance and activity of the

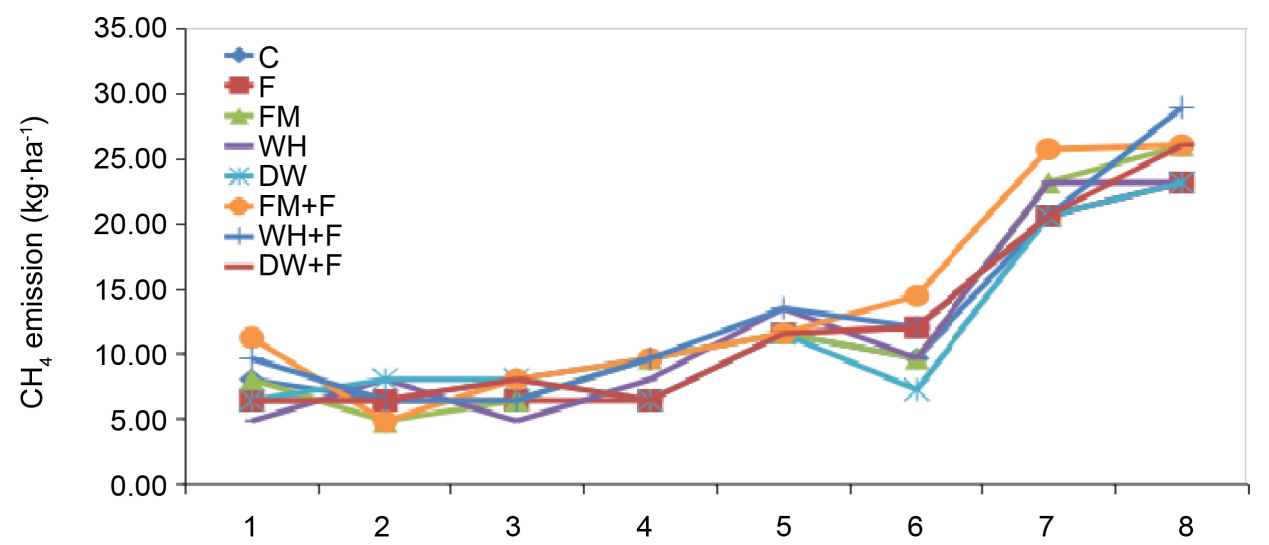

Figure 5. Change in $\mathrm{CH}_{4}$ emission from Kalma soil. 
methanotrophs that oxidize it [13] [27] [29] [30]. It also attributed this to the decreased activity of methanogens along with the increased $\mathrm{CH}_{4}$ oxidation activity and $p m o A$ gene abundance of methanotrophs [31]. A meta-analysis conducted by several scientist shows that addition of biochar to non-flooded soils, particularly when neutral or alkaline, may decrease the $\mathrm{CH}_{4}$ reduction potential of those soils [18].

The average $\mathrm{CH}_{4}$ emission for each 15 day from both the soils in field condition is $6.02 \mathrm{~kg} \cdot \mathrm{ha}^{-1}$ and $19.45 \mathrm{~kg} \cdot \mathrm{ha}^{-1}$ in submerged condition. Therefore, the equivalent $\mathrm{CO}_{2}$ emission for a 100 years lifetime would be 168.5 and 544.5 $\mathrm{kg} \cdot \mathrm{ha}^{-1}$. Results in this study do not support the overwhelmed prediction of biochar's potential to suppress $\mathrm{CH}_{4}$ emission. Reviews even found $19 \%$ increase in methane emission from paddy fields after biochar application and high uncertainty in upland soils [13] [15].

\subsection{Effect on CO Emission}

The amount of $\mathrm{CO}$ evolved from the incubated soils was extremely low compared to evolved $\mathrm{CO}_{2}$ and $\mathrm{CH}_{4}$. The Figure 6 and Figure 7 demonstrates the emission trends of $\mathrm{CO}$ from two agricultural soils of Bangladesh at varying incubation days. The results are expressed as gram per hectare. The carbon monoxide emission from biochar treated Sara soils were higher than the control or only fertilized ones. Especially the non-fertilized biochar treatments emitted higher degrees of $\mathrm{CO}$ than other treatments at the first sampling date, but this trend inverted from the second sampling date to the end of the field condition. At the last recording date of the aerobic treatment, overall emission increased significantly ranging from 5.50 to $15.87 \mathrm{~g} \cdot \mathrm{ha}^{-1}$ except for the FM treatment ( 0.46 $\left.\mathrm{g} \cdot \mathrm{ha}^{-1}\right)$. From the beginning of the submerged condition, $\mathrm{CO}$ emission increased a couple of folds $(\mathrm{p}<0.001)$ than field condition specially for the $\mathrm{C}$ and $\mathrm{F}$ treatment which became the greatest emitter (32.50 and $33.25 \mathrm{~g} \cdot \mathrm{ha}^{-1}$, respectively) in submerged condition. In this phase, only biochar application caused greater emission than that of their fertilized counterparts and this trend continued to the end of the incubation period. The $\mathrm{CO}$ emission was recorded the minimum at $105^{\text {th }}$ day in this anaerobic stage of incubation. Water hyacinth biochar set up to be the mean highest emitting biochar treatment. Biochar treatments had a

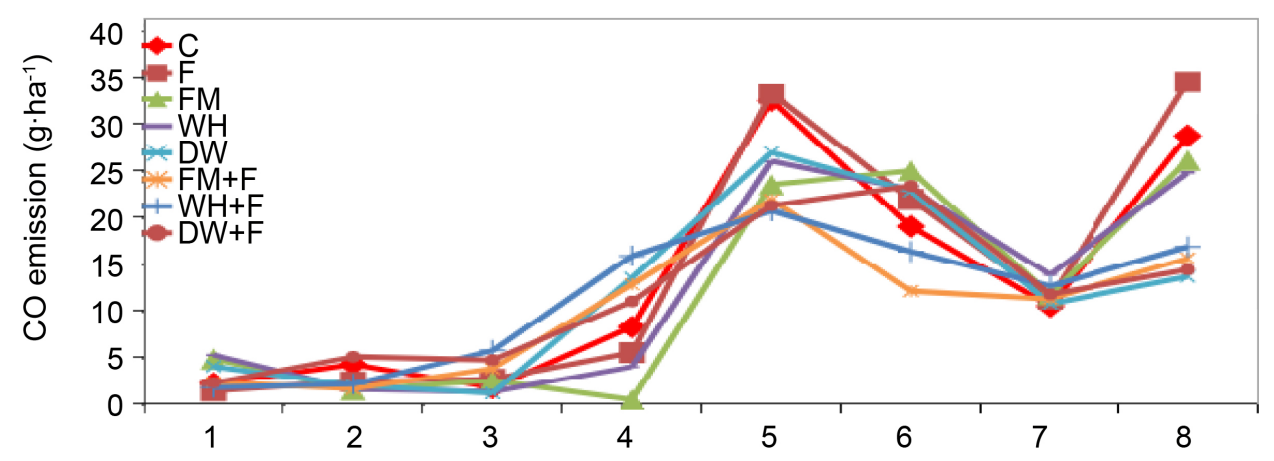

Figure 6. Change in $\mathrm{CO}$ emission from Sara soil. 


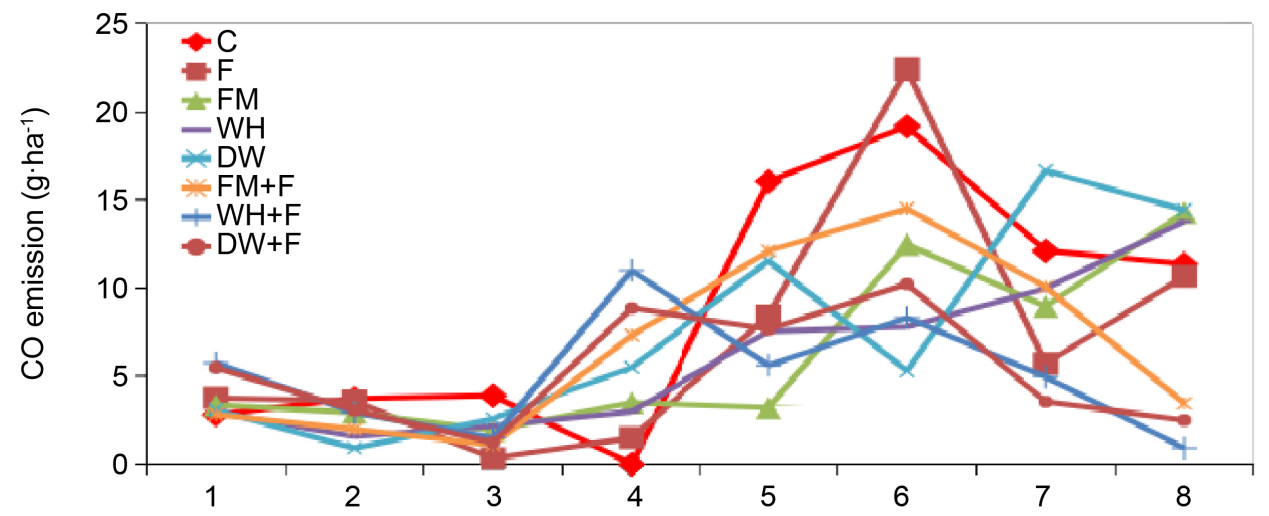

Figure 7. Change in $\mathrm{CO}$ emission from Kalma soil.

non-significant effect on CO emission from Sara soil.

The CO emission trends from the Kalma soil followed the behavior of Sara soil. At the first recording date, fertilized biochar treatments emitted a higher amount of $\mathrm{CO}$ than other treatments. This happened at the 4 th recording date as well. The overall emission was negligible and saw a lot of ups and downs throughout the aerobic incubation period. However, at the end of the 60 days, the overall emission increased with the only exception of the non-detectable level of $\mathrm{CO}$ emission from the control treatment. The control treatment became the highest emitter at the beginning of the submerged incubation period followed by the FM + F treatment (16.05 and $12.10 \mathrm{~g} \cdot \mathrm{ha}^{-1}$, respectively). By the end of the incubation period, fertilized biochar treatments became the lowest emitter of $\mathrm{CO}$ from Kalma soil. Biochar treatments did not have any significant effect in reducing $\mathrm{CO}$ emission as well. Submergence caused significantly higher emission.

The overall trend reveals the fact that carbon monoxide emission increased with submergence significantly $(\mathrm{p}<0.05)$. This study suggests that biochar incubation could not reduce the CO emission $(p>0.05)$ from soils and fertilized biochar application caused higher reduction of emission. This complies with the findings of a laboratory study conducted by a group of scientist in a Bangladeshi soil with biochar application rate of $5 \mathrm{t} \cdot \mathrm{ha}^{-1}[32]$ and results are comparable with other study as well [13] [27].

\section{Conclusion}

In Bangladesh, being a very insignificant contributor of global atmospheric carbon and a developing country, there is a huge knowledge gap on national carbon budget and sector based GHG emission inventory. This makes the planning and implementing carbon mitigation measures difficult. The Energy-intensive production process and low feedstock availability of Bangladesh would make biochar an onerous tool for carbon sequestration. Although this study doesn't support the overwhelmed carbon emission reducing potential of biochar, adequate field studies with diverse biochar sources and soils are needed before drawing any conclusion. It would be most effective if methane and nitrous oxide could be 
reduced from the rice dominated wet cultivation practice of Bangladesh. However, biochar's potential to improve soil fertility, organic matter content and to amend problem soils would be the key factors to be considered before deciding its prospects in Bangladesh.

\section{References}

[1] Pachauri, R.K., Meyer, L., Plattner, G.K. and Stocker, T. (2015) IPCC, 2014: Climate Change 2014: Synthesis Report. Contribution of Working Groups I, II and III to the Fifth Assessment Report of the Intergovernmental Panel on Climate Change, IPCC, 151.

[2] Wang, Y.Y., Hu, C.S., Ming, H., Zhang, Y.M., Li, X.X., Dong, W.X. and Oenema, O. (2013) Concentration Profiles of $\mathrm{CH}_{4}, \mathrm{CO}_{2}$ and $\mathrm{N}_{2} \mathrm{O}$ in Soils of a Wheat-Maize Rotation Ecosystem in North China Plain, Measured Weekly over a Whole Year. Agriculture, Ecosystems \& Environment, 164, 260-272. https://doi.org/10.1016/j.agee.2012.10.004

[3] Stocker, T., Ed. (2014) Climate Change 2013: The Physical Science Basis. Working Group I Contribution to the Fifth Assessment Report of the Intergovernmental Panel on Climate Change. Cambridge University Press, UK.

[4] Change, I.C. (2014) Mitigation of Climate Change. Contribution of Working Group III to the Fifth Assessment Report of the Intergovernmental Panel on Climate Change, Cambridge University Press, Cambridge and New York.

[5] Smith, P., Martino, D., Cai, Z., Gwary, D., Janzen, H., Kumar, P., McCarl, B., Ogle, S., O'Mara, F., Rice, C. and Scholes, B. (2008) Greenhouse Gas Mitigation in Agriculture. Philosophical Transactions of the Royal Society B: Biological Sciences, 363. https://doi.org/10.1098/rstb.2007.2184

[6] Lehmann, J., Czimczik, C., Laird, D. and Sohi, S. (2009) Stability of Biochar in Soil. Biochar for Environmental Management. Science and Technology, 183-206.

[7] Sohi, S.P., Krull, E., Lopez-Capel, E. and Bol, R. (2010) A Review of Biochar and Its Use and Function in Soil. Advances in Agronomy, 105, 47-82. https://doi.org/10.1016/S0065-2113(10)05002-9

[8] Lehmann, J. and Joseph, S. (2015) Biochar for Environmental Management: Science, Technology and Implementation. Routledge, New York.

[9] Laird, D.A., Brown, R.C., Amonette, J.E. and Lehmann, J. (2009) Review of the Pyrolysis Platform for Coproducing Bio-Oil and Biochar. Biofuels, Bioproducts and Biorefining, 3, 547-562. https://doi.org/10.1002/bbb.169

[10] DeLuca, T.H., Gundale, M.J., MacKenzie, M.D. and Jones, D.L. (2015) Biochar Effects on Soil Nutrient Transformations. Biochar for Environmental Management. Science, Technology and Implementation, 2, 421-454.

[11] Darby, I., Xu, C.Y., Wallace, H.M., Joseph, S., Pace, B. and Bai, S.H. (2016) Short-Term Dynamics of Carbon and Nitrogen Using Compost, Compost-Biochar Mixture and Organo-Mineral Biochar. Environmental Science and Pollution Research, 23, 11267-11278. https://doi.org/10.1007/s11356-016-6336-7

[12] Van Zwieten, L., Kammann, C., Cayuela, M., Singh, B.P., Joseph, S., Kimber, S., Donne, S., Clough, T. and Spokas, K. (2015) Biochar Effects on Nitrous Oxide and Methane Emissions from Soil. Biochar for Environmental Management. Science, Technology and Implementation, Routledge.

[13] He, Y., Zhou, X., Jiang, L., Li, M., Du, Z., Zhou, G., Shao, J., Wang, X., Xu, Z., HosseiniBai, S. and Wallace, H. (2017) Effects of Biochar Application on Soil Green- 
house Gas Fluxes: A Meta-Analysis. GCB Bioenergy, 9, 743-755.

https://doi.org/10.1111/gcbb.12376

[14] Zhang, A., Liu, Y., Pan, G., Hussain, Q., Li, L., Zheng, J. and Zhang, X. (2012) Effect of Biochar Amendment on Maize Yield and Greenhouse Gas Emissions from a Soil Organic Carbon Poor Calcareous Loamy Soil from Central China Plain. Plant and Soil, 351, 263-275. https://doi.org/10.1007/s11104-011-0957-x

[15] Song, X., Pan, G., Zhang, C., Zhang, L. and Wang, H. (2016) Effects of Biochar Application on Fluxes of Three Biogenic Greenhouse Gases: A Meta-Analysis. Ecosystem Health and Sustainability, 2, e01202.

[16] Tongwane, M., Mdlambuzi, T., Moeletsi, M., Tsubo, M., Mliswa, V. and Grootboom, L. (2016) Greenhouse Gas Emissions from Different Crop Production and Management Practices in South Africa. Environmental Development, 19, 23-35.

[17] Denman, K.L., Brasseur, G.P., Chidthaisong, A., Ciais, P., Cox, P.M., Dickinson, R.E., Hauglustaine, D.A., Heinze, C., Holland, E.A., Jacob, D.J. and Lohmann, U. (2007) Couplings between Changes in the Climate System and Biogeochemistry. In: Solomon, S., Qin, D., Manning, M., Chen, Z., Marquis, M., Averyt, K.B., Tignor, M. and Miller, H.L., Eds., Climate Change 2007: The Physical Science Basis, Cambridge University Press, Cambridge, Chapter 7.

[18] Jeffery, S., Verheijen, F.G., Kammann, C. and Abalos, D. (2016) Biochar Effects on Methane Emissions from Soils: A Meta-Analysis. Soil Biology and Biochemistry, 101, 251-258. https://doi.org/10.1016/j.soilbio.2016.07.021

[19] Prather, M.J. (1996) Time Scales in Atmospheric Chemistry: Theory, GWPs for CH4 and CO, and Runaway Growth. Geophysical Research Letters, 23, 2597-2600. https://doi.org/10.1029/96GL02371

[20] Potter, C.S., Klooster, S.A. and Chatfield, R.B. (1996) Consumption and Production of Carbon Monoxide in Soils: A Global Model Analysis of Spatial and Seasonal Variation. Chemosphere, 33, 1175-1193.

[21] Hertwich, E.G. and Peters, G.P. (2009) Carbon Footprint of Nations: A Global, Trade-Linked Analysis. Environmental Science \& Technology, 43, 6414-6420. https://doi.org/10.1021/es803496a

[22] FAO (2017) Rice Market Monitor. Trades and Market Division. Food and Agriculture Organization of the United Nations, Vol. 20, 1-38.

[23] Khan, R.U. and Saleh, A.F.M. (2015) Model-Based Estimation of Methane Emission from Rice Fields in Bangladesh. Journal of Agricultural Engineering and Biotechnology, 3, 125-137.

[24] USDA (United States Department of Agriculture) (1951) Soil Survey Manual. Soil Survey Staff, Bureau of Plant Industry, Soil and Agricultural Engineering, United States Department of Agriculture, Washington DC, 18, 205.

[25] Piash, M.I., Hossain, M.F. and Parveen, Z. (2017) Physico-Chemical Properties and Nutrient Content of Some Slow Pyrolysis Biochars Produced from Different Feedstocks. Bangladesh Journal of Scientific Research, 29, 111-122. https://doi.org/10.3329/bjsr.v29i2.32327

[26] Web 1: Online Fertilizer Recommendation System. http://frs-bd.com/

[27] Liu, Y., Wan, K.Y., Tao, Y., Li, Z.G., Zhang, G.S., Li, S.L. and Chen, F. (2013) Carbon Dioxide Flux from Rice Paddy Soils in Central China: Effects of Intermittent Flooding and Draining Cycles. PLoS ONE, 8, e56562.

https://doi.org/10.1371/journal.pone.0056562

[28] Liu, Y., Yang, M., Wu, Y., Wang, H., Chen, Y. and Wu, W. (2011) Reducing $\mathrm{CH}_{4}$ and $\mathrm{CO}_{2}$ Emissions from Waterlogged Paddy Soil with Biochar. Journal of Soils and 
Sediments, 11, 930-939. https://doi.org/10.1007/s11368-011-0376-x

[29] Feng, Y., Xu, Y., Yu, Y., Xie, Z. and Lin, X. (2012) Mechanisms of Biochar Decreasing Methane Emission from Chinese Paddy Soils. Soil Biology and Biochemistry, 46, 80-88. https://doi.org/10.1016/j.soilbio.2011.11.016

[30] Khan, S., Chao, C., Waqas, M., Arp, H.P.H. and Zhu, Y.G. (2013) Sewage Sludge Biochar Influence upon Rice (Oryza sativa L.) Yield, Metal Bioaccumulation and Greenhouse Gas Emissions from Acidic Paddy Soil. Environmental Science \& Technology, 47, 8624-8632. https://doi.org/10.1021/es400554x

[31] Han, X., Sun, X., Wang, C., Wu, M., Dong, D., Zhong, T., Thies, J.E. and Wu, W. (2016) Mitigating Methane Emission from Paddy Soil with Rice-Straw Biochar Amendment under Projected Climate Change. Scientific Reports, 6, Article No. 24731. https://doi.org/10.1038/srep24731

[32] Mahmud, K., Chowhdhury, M.S., Noor, N. and Huq, S.M.I. (2014) Effects of Different Sources of Biochar Application on the Emission of a Number of Gases from Soil. Canadian Journal of Pure and Applied Sciences, 8, 2813-2824. 